\title{
Prasa Komitetu Centralnego Komunistycznej Partii Zachodniej Białorusi (KC KPZB) wydawana w języku rosyjskim
}

Zarys treści: Niniejszy artykuł przedstawia historię nielegalnych wydawnictw prasowych Komitetu Centralnego Komunistycznej Partii Zachodniej Białorusi (KC KPZB) wydawanych częściowo bądź całkowicie w języku rosyjskim. We wstępie scharakteryzowano sieć podziemnych drukarni KPZB oraz redakcji, a także nazwiska i pseudonimy działających w nich członków partii. W dalszej części opisano historię grupy rozłamowej (zwanej secesją) oraz wydawanych przez nią organów prasowych, a także historię rozprawienia się z tą grupą przez KC KPZB. Następnie opisano historię kolejnych organów prasowych KC KPZB wydawanych w języku rosyjskim, skład osobowy redakcji, okres wydawania gazet, sposób redagowania, poruszaną na ich łamach tematykę, skalę ich popularności wśród członków partii oraz ocenę ich poziomu merytorycznego przez Komitet Centralny partii.

Outline of content: This article presents an overview of the illegal press publications of the Central Committee of the Communist Party of Western Belarus (CC CPWB) written partly or entirely in Russian. The article begins by characterising the network of underground printing and editorial offices of the CC CPWB, as well as the names and pseudonyms of the party members active therein. The subsequent section recounts the splinter group (called „secession”) and its own press releases, as well as the aftermath of its conflict with the CC CPWB. And finally, the article describes the different Russian-language press titles of the CC CPWB, the composition of their editorial boards, their periods of publication, their editing methods, the subjects raised, the scale of their popularity among party members and the substantive evaluation of their work by the Central Committee of the party.

Słowa kluczowe: Komunistyczna Partia Zachodniej Białorusi, KPZB, prasa komunistyczna w latach 1923-1938, ruch komunistyczny w czasach II Rzeczpospolitej, Wilno

Keywords: CPWB, communist press 1923-1938, communist movement in Second Republic of Poland, USSR, Vilnius 
Istniejąca w latach 1923-1938 jako autonomiczna część Komunistycznej Partii Robotniczej Polski (KPRP), od roku 1925 funkcjonującej pod nazwą Komunistyczna Partia Polski (KPP) Komunistyczna Partia Zachodniej Białorusi (KPZB) doczekała się kilku opracowań w języku polskim i rosyjskim ${ }^{1}$, w których mniej lub bardziej obszernie opisywano jej historię, jednakże zdecydowana większość z nich powstała w czasach PRL oraz ZSRR, przez co miały one w znacznym stopniu charakter propagandowy i nie przedstawiały w pełni obiektywnie działalności tej partii. Celem niniejszego artykułu jest opisanie historii nielegalnych wydawnictw prasowych wydawanych przez Komitet Centralny KPZB, a konkretnie tej jej części, która ukazywała się częściowo bądź całkowicie w języku rosyjskim. Prasa KPZB doczekała się swojej monografii w języku rosyjskim ${ }^{2}$, była też obszernie opisywana w wydanej w języku białoruskim monografii dotyczącej historii dziennikarstwa na Białorusi ${ }^{3}$, jak również w obszernym artykule dotyczącym historii prasy białoruskiej na terenie II Rzeczypospolitej ${ }^{4}$. Z nowszych dzieł warto wspomnieć również o opublikowanej w języku rosyjskim pracy poświęconej prasie wydawanej przez podległą na obszarze

1 W latach 60. i 70. XX wieku powstało kilkanaście publikacji dotyczących KPZB oraz jej działaczy, a także innych białoruskich organizacji kryptokomunistycznych autorstwa byłej członkini tej partii Aleksandry Bergman, które zostały potem opublikowane zbiorowo w pracy pod tytułem Sprawy białoruskie w II Rzeczypospolitej, Warszawa 1984. Istnieje również biogram sekretarza Biura KC KPZB Józefa Łohinowicza autorstwa innego byłego działacza KPP Szymona Zachariasza: Józef Łohinowicz (Paweł Korczyk), „Z Pola Walki”, nr 3(15), 1961, s. 212-237. Kwestia KPZB była również poruszana w pracach Henryka Cimka dotyczących ruchu komunistycznego w II Rzeczypospolitej. Z najważniejszych prac tego badacza na ten temat można wymienić Białorusini w ruchu rewolucyjnym w II Rzeczypospolitej, [w:] Kwestia narodowościowa w Polsce $i$ we Włoszech $w$ XX wieku. Wybrane problemy, red. idem, Rzeszów 2011, s. 11-34, Komuniści-Polska-Stalin, Białystok 1990; Mniejszości narodowe w ruchu rewolucyjnym w II Rzeczypospolitej, Rzeszów 2011, Sojusz robotniczo-chłopski w Polsce 1918-1939, Warszawa 1989. W języku rosyjskim i białoruskim opublikowano wiele opracowań na ten temat, m.in.: Т. Глинская, КПЗБ - руководитель освободительной борьбы трудящихся Западной Белоруссии 1924-1928 г2., Mińsk 1965; В. Ф. Ладысев, В борьбе за демократические права и свободы, Mińsk 1988; idem, КПЗБ - арганизатар барацьбы прачоўных за демакратычныя правы и свабоды (1934-1938 г2.), Mińsk 1976; В. А. Полуян, Революиионно-демократическое движение в Западной Белоруссии, Mińsk 1978; Революиионньй путь Компартии Западной Белоруссии, red. А. Мацко, В. Самутин, Mińsk 1966; Г. Б. Воткович, КПЗБ в борьбе за интернационалное единство трудящихся (1929-1933 г2.), Mińsk 1975. Już po powstaniu niepodległego państwa białoruskiego powstało w języku rosyjskim opracowanie poświęcone działalności Międzynarodowej Organizacji Pomocy Rewolucjonistom (MOPR): T. A. Лугачиова, Международная Организация Помощзи Революиионерам (МОПР) в Западной Белоруссии (1923-1939 г.), Grodno 2001. Z nowszych prac w języku polskim warto zwrócić uwagę na artykuły poświęcone działalności KPZB w Wilnie w pierwszej połowie lat 30. oraz na Polesiu pod koniec tej dekady. Zob. P. Cichoracki, Ostatnie lata działalności KPZB (1935-1938). Przypadek Polesia, „Białoruskie Zeszyty Historyczne”, nr 45, 2015, s. 185-197; S. Łukasiewicz, Zdrada stanu. Działalność Komunistycznej Partii Zachodniej Białorusi w Wilnie w latach 1930-1935, „Ogrody nauk i sztuk”, nr 2, 2012, s. 75-86, wersja elektroniczna http://nowadays.home.pl/ $\mathrm{ONiS} /$ data/documents $/ \mathrm{ONiS}=202=20=282012=29=2075-86 . p d f$, dostęp 6 XII $2014 \mathrm{r}$.

2 П. И. Зелинский, Н. А. Ракевич; Печать КПЗБ в борьбе за свободу, Mińsk 1977.

3 Р. В. Булацки, И. И. Сачанка, С. В. Говин; Гисторыя беларускай журналистыки, Mińsk 1979.

4 J. Traczuk, Prasa białoruska w II Rzeczypospolitej (1918-1939), [w:] „Studia polono-slavica orientalia. Acta litteraria”, t. XIII, 1992, s. 185-342. Choć praca została wydrukowana dopiero po upadku 
północno-wschodnich województw II Rzeczypospolitej KPZB Międzynarodową Organizację Pomocy Rewolucjonistom (MOPR) ${ }^{5}$. Wszystkie wymienione opracowania, $\mathrm{z}$ wyjątkiem ostatniego, również powstały w czasach obowiązywania komunistycznej ideologii, co miało negatywny wpływ na ich wartość badawczą. Roczniki rosyjskojęzycznej prasy KC KPZB niestety przetrwały do naszych czasów jedynie w stanie fragmentarycznym. W czasach PRL były one przechowywane w Centralnym Archiwum Komitetu Centralnego Polskiej Zjednoczonej Partii Robotniczej (CA KC PZPR), natomiast po rozwiązaniu tej placówki archiwalnej w roku 1990 częściowo trafiły do Archiwum Akt Nowych (AAN) ${ }^{6}$, po części zaś do Wydziału Zbiorów Historii Społecznej Biblioteki Sejmowej. Ponadto kilka numerów secesyjnego „Болшевика” zachowało się w zbiorach Biblioteki Uniwersytetu Warszawskiego (BUW). Pojedyncze numery, lub ich części, przechowywane są również w Bibliotece Litewskiej Akademii Nauk im. Wróblewskich w Wilnie oraz Państwowym Archiwum Obwodu Brzeskiego w Brześciu nad Bugiem. Poza tym informacji dotyczących poruszanego zagadnienia dostarcza przechowywany obecnie we wspomnianym AAN zespół Komunistycznej Partii Zachodniej Białorusi, a ze źródeł drukowanych wydane w języku rosyjskim wspomnienia jednego z ważniejszych działaczy KPZB Mikołaja Orechwy ${ }^{7}$ oraz wydrukowane w języku białoruskim jeszcze przed II wojną światową wspomnienia innego znaczącego działacza tej partii Salomona Millera (opublikowane pod pseudonimem I. R. Walewicz) ${ }^{8}$, a także wydany w dwóch tomach w latach 60. i 70. XX wieku zbiór dokumentów dotyczących działalności KPZB w czasach II Rzeczypospolitej9.

Autonomiczna KPZB została powołana do życia na II Zjeździe KPRP w 1923 r., kiedy to zdecydowano również o wejściu w jej skład wszystkich organizacji komunistycznych działających na terenie województw wileńskiego, białostockiego, nowogródzkiego oraz wileńskiego. W jej szereg z dniem 30 XII 1923 r. weszła również inna komunistyczna organizacja działająca na terenie tych województw: Białoruska Organizacja Rewolucyjna (BOR), której kierownicy: Józef Łohinowicz, Leopold Rodziewicz oraz Arseniusz Konczewski mieli w przyszłości odegrać znaczącą rolę $\mathrm{w}$ ruchu komunistycznym w tej części II Rzeczypospolitej ${ }^{10}$. Zdecydowaną więk-

ustroju komunistycznego w Polsce, to powstała ona znacznie wcześniej, w drugiej połowie lat 80 . Zob. Od redakcji, [w:] ibidem, s. 6.

5 T. A. Ługacziowa, Pieczat' MOPRa Zapadnoj Biełarusi kak istocznik izuczienija diejatiel'nosti organizacii w 20-30-e gg. XX w., [w:] Aktualnyja prablemy krynicaznaŭstwa ajczynnaj historyi, red. A. M. Dulaŭ, Witebsk 2011, s. 172-175.

6 E. Mironowicz, Prasa białoruska pod okiem rosyjskiej i polskiej cenzury, „Białoruskie Zeszyty Historyczne", nr 1(5), 1996, s. 72, przypis 11.

7 Н. С. Орехво, Дела и люди КПЗБ. Воспоминания, Mińsk 1983.

8 И. Р. Валевич, Першия гади Компартыи Заходняй Беларуси. Успамины падполщика 1921-1925 22., Mińsk 1935.

9 Борьба трудящихся Западной Белоруссии за социальное и национальное освобождение и воссоединение с БССР. Документы и материалы, red. В. И. Гурский, Н. С. Орехво, В. А. Полуян, t. 1-2, Mińsk 1962, 1972.

10 A. Bergman, Sprawy białoruskie..., s. 21-23, 53-54. 
szość członków KPZB stanowili chłopi. Jej liczebność nigdy nie wyniosła więcej niż 4 tysiące osób (stan na marzec 1933), najczęściej mieściła się ona w przedziale 2-3,5 tysiąca osób. Jeżeli chodzi o skład etniczny partii, to według Henryka Cimka w czasie funkcjonowania partii przeciętnie przedstawiał się on następująco: Białorusini $-80 \%$, Żydzi - $16 \%$, Polacy - 3\%, Litwini - $1 \%{ }^{11}$. Co godne uwagi, według danych tego badacza, w szeregach partii Rosjanie stanowili niewielką liczbę, mimo że na obszarze działania KPZB mieszkało ich ponad 100 tysięcy, ponadto przynależeli oni do kryptokomunistycznej Hromady czy też Zjednoczenia Lewicy Chłopskiej „Samopomoc" (w tej ostatniej mieli stanowić ok. 1\% członków) ${ }^{12}$.

Przyczyna, dla której organy prasowe KC KPZB mimo niewielkiej liczby etnicznych Rosjan w szeregach tej partii początkowo były wydawane głównie w języku rosyjskim, była dość prozaiczna. Otóż, jak pisała była członkini tej partii i zarazem badaczka jej dziejów Aleksandra Bergman: „w nowo powstałym KC KPZB nie było nikogo władającego swobodnie językiem białoruskim, znającego sprawy białoruskie, historię Białorusi, problemy chłopskie"13. Bardzo często podobnie wyglądała sytuacja wśród szeregowych przedstawicieli tej partii. Jak wspominał po latach jeden z przedwojennych członków KPZB, działający w okolicach Hajnówki: „Wśród starszej młodzieży, do której i ja należałem, przeważała kultura rosyjska. Przeważnie wszyscy byli dobrze obznajomieni z językiem rosyjskim, stąd też w publikacjach, w pracy uświadamiającej używano często języka rosyjskiego"14. Należy jednak zwrócić uwagę na fakt, że wydawanie przez KC KPZB prasy w języku rosyjskim przeznaczonej przede wszystkim dla Białorusinów nie było w II Rzeczypospolitej niczym wyjątkowym. Prasę w języku rosyjskim przeznaczoną dla ludności białoruskiej zamieszkującej obszar II Rzeczypospolitej wydawały również polskie organizacje społeczne oraz partie polityczne, jak na przykład nacjonalistyczne Towarzystwo Straży Kresowej (TSK), lewicowa Polska Partia Socjalistyczna (PPS) czy też kryptokomunistyczna Niezależna Partia Chłopska (NPCh) ${ }^{15}$.

11 H. Cimek, Mniejszości narodowe..., s. 64, 146-147.

12 H. Cimek, Mniejszości narodowe..., s. 82, 91; idem, Sojusz robotniczo-chłopski..., s. 248. Według danych ze spisu ludności przeprowadzonego w roku 1931 spośród 4 województw, na obszarze których działała KPZB, najwięcej Rosjan zamieszkiwało województwo wileńskie - 43 tysiące (3,4\% ogółu mieszkańców województwa). Drugim co do wielkości skupiskiem mniejszości rosyjskiej spośród wymienionych województw było województwo białostockie - 35 tysięcy $(2,1 \%$ ogółu). Po nich zaś województwo poleskie - 16 tysięcy (1,4\% ogółu) oraz nowogródzkie - 7 tysięcy ( $0,6 \%$ ogółu). Dane za: J. Tomaszewski, Ojczyzna nie tylko Polaków. Mniejszości narodowe w Polsce w latach 1918-1939, Warszawa 1985, s. 149.

13 A. Bergman, Sprawy białoruskie..., s. 57.

14 AAN, sygn. R-134, Polityka narodowościowa KPZB 1923-1938, Relacja Aleksego Osipiuka nagrana w ZHP w dn. 22 II 1962 r., k. 13.

15 Zob. więcej na ten temat w pracy Револючионный путь Компартии..., s. 146; A. R. Suławka, Prasa rosyjskojęzyczna Niezależnej Partii Chtopskiej (NPCh) w latach 1924-1927, „Białoruskie Zeszyty Historyczne”, nr 41, 2014, s. 107-125; N. Zielińska, K. Zieliński; Prasowe inicjatywy wydawnicze Towarzystwa Straży Kresowej w latach 1918-1922, [w:] „Studia Bibliologiczne Akademii Świętokrzyskiej", t. VII, 2003, s. 70-71, 76. 
Pod koniec 1923 r. Sekretariatowi KC KPZB podlegała Centralna Redakcja oraz Centralna Technika. Ta pierwsza gromadziła materiały przeznaczone dla wydawnictw partyjnych, druga zaś zajmowała się organizowaniem podziemnych drukarni oraz wydawaniem i rozpowszechnianiem nielegalnej prasy partyjnej. Zwraca uwage fakt, że Centralna Redakcja była podzielona na redakcję krajową, która miała swoje siedziby w Wilnie, Białymstoku oraz w Warszawie, oraz redakcję zagraniczną, którą zlokalizowano w Mińsku, przy tamtejszym przedstawicielstwie KC KPZB ${ }^{16}$. Z pewnością nie miało to korzystnego wpływu na działalność wydawniczą partii. W skład tej ostatniej redakcji wchodzili: R. S. Kagan pseud. „Roza”, „Nastia”; D. I. Rozenstein pseud. „Wiktor”, „Białowieżec”, „Winczuk”; M. A. Blinczykow pseud. „Jakowlew”, Jerzy Pużański (A. A. Olszewski) pseud. Jurka, A. Cukerman pseud. Zorki, Zarecki; Leopold Rodziewicz pseud. „Anatol”, „Wasyl”, „A. Stalewicz”; Stanisław Budzyński pseud. „Tradycja”, „Stach”, „S. B. T., Mikołaj Orechwo a także Paweł Horbacewicz (Piotr A. Klincewicz) oraz Jakub Winogradow (Jehuda Kamieniecki) ${ }^{17}$. Wśród autorów artykułów publikowanych na łamach prasy KPZB byli m.in. Wiera Choruża pseud. „Wiera”, S. T. Miller pseud. „Partyjec”, „Roboczy”; K. I. Osypik pseud. „Daniło”, A. M. Rozenstein pseud. „Robert”, „Maksymowski”; M. S. Majski pseud. „Benek”, H. R. Keller pseud. „Kostia” ${ }^{18}$.

Jeżeli chodzi o Centralną Technikę, to kierownictwo nad nią sprawowali w różnych okresach m.in. G. I. Rozenstein pseud. „Cezar”, „Wacek”; G. Pieńczański pseud. „Doktor”, a także M. Żukowski ${ }^{19}$. Pierwsza podziemna typografia podległa KC KPZB została zorganizowana wiosną 1924 r. w Białymstoku; była ona kierowana przez J. Kuśnieżycką i B. Epsteina. Kolejną założono jesienią tego roku w Wilnie. To właśnie ona odegrała szczególnie ważną rolę w wydaniu partyjnej prasy, o czym szerzej w dalszej części tekstu. Inną drukarnię założono w 1926 r. w Grodnie w mieszkaniu członka partii Ilji Pata, przystosowaną do wydawania literatury w pięciu językach. Ponadto w roku 1928 założono kolejną typografię w Wilnie, w domu przy ulicy Krupniczej 1. Była ona przystosowana do wydawania prasy w języku polskim, białoruskim, litewskim, rosyjskim i jidysz. Jej pracownikami byli N. Teitelbaum, G. A. Romm, A. G. Pytkowska, A. M. Szkurnik. Ponadto dla dystrybuowanej z Wilna literatury istniały pomocnicze typografie w Warszawie (w mieszkaniu członka partii Artura Fürsta) oraz w Białymstoku (w mieszkaniu niejakiego Zlatkiewicza). Ponadto w latach 1930-1931 funkcjonowała w Wilnie jeszcze jedna podziemna typografia, pod magazynem przy skrzyżowaniu ulic Końskiej i Bazyliańskiej, również przystosowana do wydawania prasy w pięciu językach. Jej pracownikami byli Natan Szogan pseud. „Dymek” (który był szczególnie zasłużony w dziedzinie organizacji podziemnych drukarni partyjnych), a także wspomniani wcześniej G. A. Romm, A. G. Pytkowska, A. M. Szkutnik. Czas pracy drukarzy miał wynosić nawet 16-20

16 П. И. Зелинский, Н. А. Ракевич, оp. cit., s. 10-11.

17 Ibidem, s. 11.

18 П. И. Зелинский, Н. А. Ракевич, ор. cit., s. 12; Н. С. Орехво, ор. cit., s. 145-147.

19 П. И. Зелинский, Н. А. Ракевич, op. cit., s. 12. 
godzin na dobę. KPZB posiadało również niewielką typografię w Brześciu przeznaczoną dla potrzeb okręgów brzeskiego i pińskiego ${ }^{20}$.

Tak jak już wcześniej wspomniano, w kwestii wydawania nielegalnej prasy przez KC KPZB główną rolę odgrywało miasto Wilno. Jak słusznie zauważał Sergiusz Łukaszewicz, z jednej strony jako największe miasto regionu było dogodnym miejscem dla prowadzenia działalności konspiracyjnej ( $w$ tym wydawania nielegalnej prasy); lecz z drugiej strony działalność konspiracyjną utrudniał fakt, że było ono wówczas w zdecydowanej większości zamieszkałe przez ludność polską, która raczej nie miała powodów dla popierania partii głoszącej hasła wymierzone w państwo polskie (wśród mniejszości narodowych zamieszkujących Wilno KPZB zresztą również nie cieszyła się zbytnim poparciem). Główną przyczyną niechęci polskiej części mieszkańców Wilna do tej partii był niewątpliwie fakt, że od czasu II Zjazdu KPZB, podobnie jak KPRP opowiadała się za „samostanowieniem aż do oderwania” tej części II Rzeczypospolitej, którą ona sama określała „Zachodnią Białorusią”. $\mathrm{Na}$ terenie Wilna oprócz tajnych drukarni znajdowały się również tajne magazyny, $\mathrm{w}$ których przechowywano nielegalną prasę. W przypadku utraty jednego $\mathrm{z}$ lokali prasę przechowywano również w piwnicach i na strychach. Jeżeli chodzi o wydatki partii na partyjne wydawnictwa, to wiadomo, że w roku 1930 miesięczny budżet KPZB wynosił 3300 zł, z czego na działalność na terenie Wilna (zwłaszcza techniczną) przeznaczano $600 \mathrm{zł}^{21}$. Już jednak na samym początku swojej działalności prasowej partia ta napotkała bardzo poważne problemy.

Na II Konferencji KPZB uaktywniła się bowiem grupa tzw. secesjonistów. Na jej czele stanął Michał Guryn używający również nazwisk Chaniewicz oraz Morozowski (zaś w pracy partyjnej pseudonimów „Jan” oraz „Stach”) ${ }^{22}$. Kierowana przez niego grupa opowiadała się przeciwko zwierzchnictwu KPP nad partią. Sam Guryn miał podzielać stanowisko Trockiego w kwestii natychmiastowej rewolucji. Jego grupa

20 А. Bergman, Sprawy białoruskie..., s. 25; П. И. Зелинский, Н. А. Ракевич, ор. cit., s. 12-14.

21 S. Łukasiewicz, op. cit., s. 76-79.

22 Michał Guryn - z pochodzenia Białorusin, urodził się w 1893 r. w Jerominach w powiecie nowogródzkim jako Michał Chaniewicz. Ukończył 4-klasową szkołę w Mirze, a następnie w $1908 \mathrm{r}$. zaczął uczęszczać do Szkoły Agronomicznej w Pskowie. W 1908 r. aresztowany pod zarzutem przynależności do partii eserowskiej. Po 8 miesiącach aresztu zwolniony i odesłany do rodzinnej miejscowości. W roku 1910 powrócił do Pskowa, gdzie rozpoczął naukę w Instytucie Nauczycielskim. Trzy lata później pod zarzutem prowadzenia wrogiej państwu działalności zesłany do guberni Wołogodzkiej. Po wybuchu I wojny światowej wcielony do armii. Po upadku caratu działał w partii eserowskiej, w listopadzie 1917 r. odesłany na Ukrainę, gdzie miał nabrać sympatii do komunizmu. Od roku 1920 w Moskwie, gdzie został przydzielony do Wydziału Białoruskiego w Komisariacie Ludowym do Spraw Narodowościowych. Następnie w Mińsku, gdzie z ramienia Komitetu Centralnego Komunistycznej Partii Białorusi został skierowany do działalności agitacyjnej wśród wiejskich nauczycieli. Ponadto redagował komunistyczne pisma „Звезда”, „Białoruska Wioska”, „Совецкая Беларусь” oraz „Боротьба”. W roku 1924 skierowany do Polski, do pracy w KPZB. Zob. AAN, KPZB sygn. 163/V-77, Wyciągi z materiałów śledztwa w sprawie prowokacyjnej roli Michała Guryna; Wyciągi z materiałów śledztwa, k. 1-3; A. Bergman, Gurin (Guryn, Góryn) Michat (1893-1928), [w:] Stownik biograficzny działaczy polskiego ruchu robotniczego, red. F. Tych, Warszawa 1987, t. II, s. 433-434; eadem, Sprawy biatoruskie... s. 32, П. И. Зелинский, Н. А. Ракевич; ор. cit., s. 24. 
miała znajdować się również pod wpływami poglądów mienszewików, eserowców, anarchistów oraz białoruskich nacjonalistów. Wraz ze swymi zwolennikami domagał się rozpoczęcia natychmiastowej walki zbrojnej na północno-wschodnich terenach II Rzeczypospolitej i utworzenia niezależnej od warszawskiej KPRP KPZB. Uzyskał on poparcie innego działacza Ernesta Polipienki używającego pseudonimów „Stary”, „Jasiński” oraz „Staszewski” oraz „Tomaszewski”. Polipienko był etnicznym Polakiem, urodził się w $1887 \mathrm{r}$. i w przeszłości był członkiem PPS, PPS-Lewicy oraz Komunistycznej Partii Litwy i Białorusi. Ważnymi współpracownikami Guryna zostali również Leopold Rodziewicz oraz Andrzej Kapucki pseud. „Loksa”. Wszyscy oni utworzyli tzw. Tymczasowy Komitet Centralny KPZB ${ }^{23}$. Józef Łohinowicz tak opisywał „nacjonalistyczne” odchylenie secesjonistów: „Secesja rozwijała tezy, [że] u nas nie ma klas, u nas nie ma warstw, u nas jest jeden naród"24. Co prawda około marca 1925 r. Rodziewicz i Kapucki zostali przekonani przez tegoż Łohinowicza do opuszczenia szeregów secesjonistów ${ }^{25}$, jednakże wcześniej grupa ta zdążyła sprawić partii wiele problemów związanych $\mathrm{z}$ działalnością wydawniczą.

Tak się bowiem złożyło, że założycielem podległej KPZB nielegalnej drukarni w Wilnie był wspomniany wcześniej współpracownik Guryna, „Stary”26. Swoją działalność typografia ta rozpoczęła w listopadzie 1924 roku. Pierwszą wydawaną przez nią gazetą był jednak białoruski „Чырвоны Сцяг”, będący kontynuacją wydawanej od roku 1920 nielegalnie na terenie Wilna rosyjskojęzycznej gazety „Красное Знамя” („Czerwony Sztandar”). Początkowo była ona organem prasowym Wileńskiego Okręgowego Komitetu Komunistycznej Partii Litwy i Białorusi, następnie od końca 1922 r. stała się organem Litewsko-Białoruskiego Obwodowego Komitetu Komunistycznej Partii Robotniczej Polski (KPRP) ${ }^{27}$. Ukazało się łącznie 38 numerów tej gazety. Według T. Glinskiej, przestała ona wychodzić wiosną 1923 roku $^{28}$. Typografia, w której przygotowywano „Красное Знамя” miała się mieścić w prywatnym mieszkaniu niejakiego Macieja Juszkiewicza i została zlikwidowana przez polską policję $\mathrm{w}$ dniu 13 VI $1923 \mathrm{r}^{29}$, w rezultacie czego gazeta ta nie ukazywała się przez kilkanaście miesięcy. Po białoruskojęzycznej reaktywacji nakład pisma wynosił 2 tysiące egzemplarzy ${ }^{30}$. „Чырвоны Сцяг” ukazywał się niemal aż do rozwiązania KPZB (według J. Traczuka wychodził aż do 1938 r.) ${ }^{31}$. Wkrótce potem,

23 A. Bergman, Sprawy białoruskie..., s. 32-33, 79; Т. Глинская, op. cit., s. 60; J. Pacuk, op. cit., s. 168; П. И. Зелинский, Н. А. Ракевич; оp. cit., s. 24-25; S. Zachariasz, op. cit., s. 219-220.

24 AAN, KPZB sygn. 163/I-1 t. 11, I Zjazd; Пасядзеннье 1-е, k. 69.

25 П. И. Зелинский, Н. А. Ракевич; op. cit., s. 25; J. Pacuk, Ksztattowanie się stosunku KPP i KPZB do powstania zbrojnego (1924-1925), [w:] „Zeszyty Naukowe Instytutu Nauk Politycznych”, t. II, 1975, s. 168, przyріs 20; Револющионньй путь Компартии..., s. 95-97; Н. С. Орехво, ор. cit., s. 51.

26 A. Bergman, Sprawy białoruskie..., s. 79.

27 Борьба трудящихся..., t. 1, s. 582, przypis 48; J. Traczuk, op. cit., s. 312, 328; S. Zachariasz, op. cit., s. 215.

28 Т. Глинская, op. cit., s. 47, przypis 2.

29 AAN, KPZB sygn. 163/V-73..., Обяснителная записка, k. 43.

30 Т. Глинская, op. cit., s. 47, przypis 2.

31 J. Traczuk, op. cit., s. 312. 
w grudniu 1924 r. kontrolowana przez secesjonistów drukarnia w Wilnie rozpoczęła wydawanie nowego organu teoretycznego partii w języku rosyjskim pod tytułem „Болшевик" ${ }^{2}$. Nakład tego pisma wynosił z kolei 1,5 tysiąca egzemplarzy ${ }^{33}$.

W drugim numerze czasopisma „Болшевик” ukazał się „Коммуникат”, w którym secesjoniści dość ostro atakowali KC KPRP. Zarzucali oni tej partii brak poparcia dla sprawy rewolucji na tzw. Zachodniej Białorusi, który miał odpychać od partii zwolenników działalności rewolucyjnej narodowości białoruskiej ${ }^{34}$. Był to manifest faktycznie wypowiadający posłuszeństwo kierownictwu zarówno w Warszawie (KPRP), jak i w Moskwie (Międzynarodówka Komunistyczna), który nie mógł nie spotkać się ze stosowną interwencją ze strony zainteresowanych. Już dnia 7 I 1925 r. secesjoniści od nazwy opublikowanego na łamach swojego organu prasowego dokumentu zwani „komunikatczykami” zostali potępieni w oficjalnym oświadczeniu przez Biuro Polityczne KC KP(b) $\mathrm{B}^{35}$. Z kolei wieczorem 18 stycznia tego roku do podziemnej drukarni KPZB w Wilnie wkroczyło czterech przysłanych z Warszawy ludzi, którzy rozebrali oraz zniszczyli wszystkie maszyny drukarskie, uniemożliwiając tym samym dalszą działalność wydawniczą secesjonistom ${ }^{36}$. Co ciekawe, dwa lata później zeznając przed polskim sądem, Guryn twierdził, że od tego momentu kacetowski „Болшевик” był drukowany poza Polską, w Mińsku w budynku przy ulicy Sadowej 19, a następnie przemycany za granicę do Polski ${ }^{37}$. Choć jak wynika z zachowanych źródeł, o czym szerzej w dalszej części tekstu, w tym czasie „Болшевик” istotnie był przygotowywany głównie w Mińsku, to nie można wykluczyć, że w jakimś stopniu prace nad kolejnymi numerami miały miejsce również w Wilnie.

Odzyskanie pism „Болшевик” oraz „ Чырвоны Сцяг” przez kierownictwo KPZB nie oznaczało jednak końca działalności secesjonistów oraz wydawanego przez nich organu. Tzw. „Secesja” cieszyła się poparciem wśród części członków okręgowych komitetów w Wilnie i Grodnie (siedmiu członków tego komitetu zostało szybko zawieszonych za kontakty z secesjonistami) oraz rejonowych komitetów w Mołodecznie i Wołożynie. Ponadto miała ona się cieszyć niewielkim poparciem wśród członków rejonowych komitetów w Krynkach, Brzostowicy Wielkiej, Kosowie oraz Prużanie. To właśnie w tych rejonach miał być rozpowszechniany drukowany

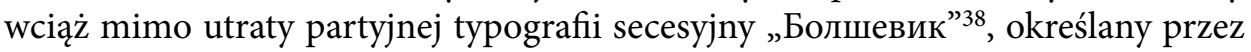

32 П. И. Зелинский, Н. А. Ракевич; op. cit., s. 7-8.

33 Т. Глинская, op. cit., s. 47.

34 Коммуникат, „Болшевик”, nr 2, 31 XII 1924, s. 1-2. Zob. także Революиионный путь Компартии..., s. 97.

35 J. Pacuk, op. cit., s. 169.

36 Zob. „Болшевик”, nr 4, 9 II 1925, s. 1-2. Co ciekawe, później przed polskim sądem Guryn twierdził, że wspomniany incydent miał miejsce 19 stycznia. Zob. AAN, KPZB sygn. 163/V-77...; Wyciągi z materiałów..., k. 3-4.

37 AAN, KPZB sygn. 163/V-77...; Wyciągi z materiałów..., k. 3-4.

38 AAN, KPZB sygn. 163/V-73 Sprawozdania z konferencji, okólniki, uchwały, korespondencje i in.; Ze sprawozdania z konferencji białoruskiej, k. 1; Революиионный путь Компартии..., s. 98; M. Orechwo, op. cit., s. 50-51. 
członków KPZB jako „łże-«Болшевик»”39. W odróżnieniu od swojego wydawanego przez KC KPZB imiennika był najczęściej przygotowywany na maszynie do pisania i odbijany na hektografie. Jego cena wynosiła 10 groszy. Objętość poszczególnych numerów najczęściej wynosiła 4-6 stron. Niektóre numery (na przykład numery 6, 7 i 13 z 1925 r.) wszakże były drukowane typograficznie, miały postać gazety i liczyły 2 strony objętości. Na łamach swojego „Болшевика” secesjoniści apelowali do swoich zwolenników, aby w związku z rozgromieniem partyjnej typografii przez „warszawskich” wpłacali oni środki na specjalny fundusz przeznaczony na wydawanie partyjnej prasy ${ }^{40}$. Oprócz swoich komunikatów na łamach pisma publikowali również korespondencje od czytelników (podobnie jak w wypadku kacetowskiego „Болшевика” były one napisane głównie w języku białoruskim). Na łamach kontrolowanego przez partię „Болшевика” potępiono wydawanie przez secesjonistów pisma pod tym samym tytułem, twierdząc, że secesja nie ma nic wspólnego z ideologią bolszewizmu, a także że jej organ prasowy nie ma prawa podszywać się pod organ $\mathrm{KC} \mathrm{KPZB}^{41}$.

Istnienie dwóch KC KPZB wydających dwa organy prasowe pod tytułem „Болшевик” nie miało jednak trwać zbyt długo. Pierwszym ciosem w redakcję „secesyjnego" pisma było wspomniane wcześniej opuszczenie szeregów secesji przez Rodziewicza i Kapuckiego, którzy brali również czynny udział w redagowaniu secesyjnego „Болшевика”42. Poza tym, o czym była mowa wcześniej, „Secesja” stopniowo traciła poparcie wśród szeregowych członków KPZB, choć jeszcze w lipcu 1925 r. udało jej się wysłać swoich przedstawicieli na okręgową konferencję KPZB $\mathrm{w}$ Wilnie ${ }^{43}$. Niedługo potem spotkał ją jednak kolejny cios w postaci aresztowania jej przywódcy Michała Guryna przez polską policję w dniu 28 września 1925 roku. Wkrótce po schwytaniu podjął on z nią czynną współpracę, dzięki której wyszedł na wolność w dniu 2 czerwca 1926 roku. Jego zeznania były bardzo pomocne w procesie Bronisława Taraszkiewicza i innych członków kryptokomunistycznej BWRH „Hromady”44. Pod koniec 1926 r. na łamach „Болшевика” і „Чырвоного Сцяга” pojawiły się artykuły informujące o współpracy Guryna z polską policją wraz z jego zdjęciem oraz ostrzeżeniem członków partii przed jego osobą ${ }^{45}$. Według

39 Н. С. Орехво, ор. cit., s. 51; И. Р. Валевич, ор. cit., s. 37-38.

40 Zob. „Болшевик”, nr 5, 20 lutego 1925, s. 4.

41 Zob. Резолуиия до докладуи ЦК КПЗБ, „Болшевик”, nr 1(5), 15 II 1926, s. 2.

42 AAN, KPZB sygn. 163/V-73..., Выписка из писма, k. 17.

43 Т. Глинская, op. cit., s. 64.

44 A. Bergman, Gurin (Guryn, Góryn) Michał..., s. 433; eadem, Sprawy białoruskie..., s. 208, Sz. Rudnicki, Nieznany dokument w sprawie Sylwestra Wojewódzkiego, przypis 54, „Przegląd Historyczny” 1976, t. 47, z. 1, s. 77-78.

45 Zob. „Чырвоны Сцяг”, nr 8 (50), grudzień 1926, s. 6; „Балшавик”, nr 9-10 (14), listopad-grudzień 1926, s. 16. Po przejściu na stronę polską Michał Guryn stał się jednym z ważniejszych członków nastawionej propolsko Radykalnej Ludowej Partii Białoruskiej założonej w dniu 25 X 1927 r. Partia ta w czasie wyborów parlamentarnych w 1928 r. poparła sanacyjny BBWR. Był on również jednym z założycieli utworzonego w marcu 1927 r. Towarzystwa Inteligencji Białoruskiej mającego za cel propagowanie białoruskiej kultury poprzez zwiększenie liczby szkół oraz wydawnictw białoruskich drogą 
Salomona Millera, pod koniec 1925 r. secesjoniści nie mieli już żadnego poparcia wśród działaczy komunistycznych ${ }^{46}$. Mimo to organ prasowy „Secesji” przetrwał jeszcze jakiś czas. Ostatni zachowany, 15 numer, „Болшевика” jest datowany na 20 września 1925 roku. Wiadomo jednak, że ukazało się co najmniej 20 numerów tego pisma, które były wydawane jeszcze w pierwszej połowie 1926 r., gdyż w numerze kacetowskiego „Болшевика” z maja 1926 r. zamieszczono polemikę $\mathrm{z}$ artykułami publikowanymi w tym numerze ${ }^{47}$. Faktem jednak było, że w ciągu kilkunastu miesięcy od swojego powstania grupa rozłamowa przestała stwarzać zagrożenie dla integralności KPZB.

Na przełomie lat 1925 i 1926 doszło również do zmiany metod działań przez komunistów w Polsce, także tych należących do KPZB. Wcześniej zajmowali się oni głównie tworzeniem bojówek oraz prowadzeniem działalności dywersyjnej i terrorystycznej wymierzonej w polski aparat państwowy. Jednakże dojście do władzy w ZSRR Józefa Stalina spowodowało czasową rezygnację z koncepcji natychmiastowej rewolucji światowej oraz skupienie się na oczyszczeniu własnych szeregów z osób niepopierających nowej polityki. W wypadku KPZB oznaczało to właśnie wydalenie z partii działaczy o poglądach eserowskich oraz białorusko-nacjonalistycznych, czego efektem była właśnie walka ze wspomnianą wcześniej „Secesją”, a także rozwiązanie dywersyjnych bojówek działających na północnym wschodzie II Rzeczypospolitej (wobec części z nich Sowieci musieli uciec się do siły, prowokując walki pomiędzy nimi w rejonie Kojdanowa) ${ }^{48}$. Zarówno w walce z secesjonistami, jak i w prowadzeniu całokształtu działalności rewolucyjnej znaczącą rolę miał odgrywać „odzyskany” przez partię „Болшевик”. Na czele redakcji tego pisma zdecydowano się postawić jednego z byłych współpracowników Guryna, wspomnianego wcześniej Leopolda Rodziewicza, któremu partia wybaczyła wcześniejszą „zdradę" ${ }^{\text {"9 }}$.

legalną. Jednakże w tejże działalności nie zdążył osiągnąć zbyt wiele. Został on bowiem zastrzelony w dniu 16 marca 1928 r. w Wilnie, w czasie gdy zeznawał w sądzie w procesie przeciwko członkom „Hromady”. Jego zabójca, Siemion Klincewicz, został za swój czyn skazany na karę dożywotniego więzienia w dniu 10 czerwca 1929 r. Zob. A. Bergman, Gurin (Guryn, Góryn) Michał..., s. 433-434; K. Gomółka, Białorusini w II Rzeczypospolitej, [w:] „Zeszyty Naukowe Politechniki Gdańskiej” 495, Ekonomia XXXI, Gdańsk 1992, s. 119; J. Januszewska-Jurkiewicz, Stosunki narodowościowe na Wileńszczyźnie w latach 1920-1939, Katowice 2010, s. 631, przypis 440, s. 632; В. Ф. Ладысев, В борьбе за..., s. 150; Но 376. Сообщение о суде над Клинцевичем за убийство провокатора Гурына, [w:] Борьба трудящихся..., t. 1, s. 512.

46 И. Р. Валевич, ор. cit., s. 39.

47 Острий, А Моська знать сильна, коль лает на сльона, „Болшевик”, nr 3(7), тај 1926, s. 6-7.

48 W. Śleszyński, Walka instytucji państwowych z białoruską działalnościa dywersyjna na ziemiach pólnocno-wschodnich II Rzeczypospolitej, [w:] idem, Walka instytucji państwowych z białoruską dziatalnością dywersyjna 1920-1925, Białystok 2005, s. 19-20.

49 Leopold Rodziewicz (1895-1938) - działacz rewolucyjny, literat, poeta oraz dziennikarz. Urodził się na terenie folwarku Kuprianowszczyzna w dniu 12 VI 1895 r. w rodzinie ziemiańskiej polskiego pochodzenia $\mathrm{z}$ tradycjami powstańczymi. Mimo tego w dzieciństwie posługiwał się językiem białoruskim, w tym też języku zaczął tworzyć swoje pierwsze dzieła literackie. Na początku lat 20. przebywał w Wilnie, gdzie związał się z białoruskimi środowiskami teatralnymi oraz pracował w redakcjach białoruskich gazet. Był również aktywnym działaczem wspomnianego wcześniej BOR-u. 
Jeżeli chodzi o samo pismo „Болшевик”, to kierownictwo partii wiązało z tym organem prasowym duże oczekiwania. W planie wydawniczym pisma $\mathrm{z}$ dnia 11 IX 1925 r. postanowiono, że będzie ono ukazywać się co miesiąc, a jego nakład miał wynosić nawet do 2,5 tysiąca egzemplarzy. Ponadto przewidziano stałe działy informujące o bieżących zadaniach partii, o taktyce partii, o zadaniach teoretycznych, przeglądzie politycznym sytuacji w Polsce oraz za granicą (głównie ruchów komunistycznych $z$ innych krajów), sytuacji w ZSRR oraz Białoruskiej SRR, położenia Białorusinów w innych krajach, o życiu partii, partyjnych wydawnictwach, sprawozdania $\mathrm{z}$ działalności finansowej, a także ogłoszenia redakcyjne. W zamierzeniach kierownictwa partii „Болшевик” miał wskazywać partyjnemu aktywowi właściwą „linię partyjną” oraz pomagać mu prawidłowo wykorzystywać materiały partyjne w działalności propagandowej. Postulowano również wspólne czytanie pisma na zebraniach komórek partyjnych ${ }^{50}$. Poza tym również na III Konferencji KPZB w styczniu 1926 r. postanowiono, że „Болшевик” powinien ukazywać się regularnie co miesiąc, a zarazem, że „powinien być obliczony na szerokie masy członków partii”51. Rzeczywiście, w roku 1926 gazeta ukazywała się w niemal regularnie co miesiąc. Cena wynosiła 15 groszy, ponadto stopniowo zwiększano objętość gazety, najpierw do 6, później do 8, a następnie do 12 stron. Niektóre numery były nawet obszerniejsze, licząc 16-20 stron objętości. Od grudnia $1925 \mathrm{r}$. na łamach pisma publikowano również odezwy kierowane do działaczy MOPR-u ${ }^{52}$. Oprócz oficjalnych uchwał KC KPZB niekiedy drukowano również przegląd prasy, a także, jeżeli je otrzymywano korespondencje od czytelników (te ostatnie najczęściej w języku białoruskim). Należy wszakże zwrócić uwagę, że w kwestii pozyskiwania korespondencji od czytelników osiągnięcia redakcji nie wyglądały zbyt imponująco. Zygmunt Kratko w czasie I Zjazdu partii zwracał uwagę, że dział korespondencji w „Болшевику” wynosi około pół strony, podczas gdy objętość pojedynczego numeru tego pisma w tym czasie wahała się w granicach 10 stron $^{53}$. Z kolei redaktor naczelny tego pisma Leopold Rodziewicz w czasie IV plenum KC KPZB podkreślił, że nieco wcześniej otrzymał z okręgu pińskiego 27 korespondencji jednocześnie, co nigdy wcześniej mu się nie zdarzyło. W związku $\mathrm{z}$ tym proponował, by opublikować informację o tym osiągnięciu w którymś

Po powstaniu KPZB, jak już wcześniej wspomniano, przez krótki czas był aktywnym współpracownikiem secesji, szybko jednak się z niej wycofał. Poszukiwany przez polską policję jesienią 1925 r. opuścił terytorium II Rzeczypospolitej i wyjechał do Mińska. Właśnie tam został faktycznym kierownikiem redakcji zagranicznej KC KPZB, mając olbrzymi wpływ na treść i kształt organów prasowych partii, w tym wspomnianego „Болшевика”. Działalność wydawnicza pochłonęła go do tego stopnia, że doprowadziła do rozpadu zawartego przez niego w międzyczasie małżeństwa. Zob. więcej na temat tego działacza w pracy A. Bergman, Sprawy biatoruskie..., s. 196-218.

50 AAN, KPZB sygn. 163/V-73..., Подготовка и воспитание партийного актива и центральный партийный орган „Болшевик”, k. 60-62.

51 AAN, KPZB sygn. 163/II/39, III Konferencja; Тезысы по организационному вопросу, k. 14.

52 Т. А. Лугачиова, Международная Организация..., s. 52.

53 AAN, KPZB sygn. 163/I-1 t. 11, I Zjazd; Четвертое утронные заседание 1-го Сьязда КПЗБ, k. 124. 
z partyjnych organów prasowych i stawiać to jako wzór innym organizacjom partyjnym ${ }^{54}$. Na łamach „Болшевика” zamieszczano również informacje z obszaru województwa białostockiego, które, jak zauważył Eugeniusz Mironowicz, były „zadziwiająco dokładne" 55 . Wśród autorów artykułów publikowanych na łamach tego organu partii znaleźli się m.in. Adolf Warski, Julian Leński, Salomon Miller, Anatol Olszewski ${ }^{56}$. W czasie istnienia pisma szereg artykułów na jego łamach opublikował również sekretarz KC KPZB Józef Łohinowicz (podpisywał je pseudonimami P. Korczyk, K. Pawliuczioniok) ${ }^{57}$.

Tymczasem polityka KPZB w sprawie działalności prasowej ulegała zmianie. Na II Rozszerzonym Plenum zwracano uwagę „na niedostateczną popularność” publikacji zamieszczanych zarówno na łamach „Болшевика”, jak i „Чырвоного Сцяга"58. Kierownictwo partii w rezolucji za okres czerwiec-wrzesień 1926 r. nakazało pismo „Болшевик” „uczynić popularniejszym i bardziej aktualnym”, a także „przekierować stopniowo” to pismo, podobnie jak organ KC KZMZB „Mołodoj Kommunist” "na białoruski język" ${ }^{9}$. Również w późniejszym czasie Zygmunt Kratko pseud. „Wiktor” na I Zjeździe KPZB w 1928 r. zwracał uwagę, że przedstawiciele młodego pokolenia ludności zamieszkującej obszar działań KPZB nie znają już języka rosyjskiego, w związku z tym partyjna prasa powinna być wydawana w językach polskim, żydowskim, białoruskim i litewskim (zależnie od tego, która grupa narodowościowa ma przewagę $\mathrm{w}$ danym rejonie) ${ }^{60}$. W rezultacie tych uwag od września 1926 r. główny organ Komitetu Centralnego zaczął się ukazywać pod zbiałorutenizowanym tytułem „Балшавик”, mimo to początkowo zamieszczone w nim materiały ukazywały się wciąż głównie w języku rosyjskim. Stopniowo jednak na jego łamach pojawiało się coraz więcej artykułów białoruskojęzycznych. Od drugiej połowy 1929 r. gazeta ta ukazywała się już praktycznie wyłącznie w języku białoruskim. Co godne uwagi, w tym czasie, tj. w latach 1927-1930 posiadała ona olbrzymi nakład mieszczący się granicach 15-17 tysięcy egzemplarzy. We wspomnianym okresie w niektórych miejscowościach (np. w Grodnie i Krynkach) istniały również organizowane przez okręgowe komitety KPZB niewielkie biblioteki, w których rozpowszechniano egzemplarze czasopisma ${ }^{61}$. Znaczna ilość literatury komunistycznej była dostępna również w bibliotekach żydowskich organizacji społecznych. Z czasem polska policja przeprowadzała akcje kontroli bibliotek, wskutek

54 AAN, KPZB sygn. 163/III-32, IV Plenum; Утронные заседание Пленума ЦК КПЗБ 9 VII 1930 г., k. 9.

55 E. Mironowicz, Prasa białoruska pod okiem..., s. 72.

56 J. Traczuk, op. cit., s. 258.

57 Wykaz artykułów autorstwa J. Łohinowicza w pracy Sz. Zachariasz, op. cit., s. 233-235.

58 AAN, KPZB sygn. 163/III-10, II Rozszerzone Plenum, Резолуция по догляду Секретариата ЦК КПЗБ, k. 28.

59 AAN, KPZB sygn. 163/III-11, III Plenum, Резолуция ЦК КПЗБ по отчету секретариата ЦК КПЗБ, k. 4.

60 AAN, KPZB sygn. 163/I-1 t. 11, I Zjazd; Четвертое утронные заседание..., k. 124-128.

61 Т. Глинская, ор. cit., s. 119; Г. Б. Воткович, op. cit., s. 27. 
której dochodziło do zawieszania tych, w których znajdowano pozycje propagujące ideologię komunistyczną ${ }^{62}$.

Popularność pisma wśród członków partii nie chciała wzrosnąć, o czym świadczą zachowane dokumenty partyjne. Sekretariat KC KPZB w oficjalnej uchwale z początku 1928 r. nisko oceniał praktyczne zastosowanie publikowanych w swojej prasie materiałów, jak również zarzucał jej niedostateczne informowanie o życiu i działalności partii. Zwracano również uwagę na fakt, że członkowie partii zamieszkujący w miastach rzadko zamieszczali we wspomnianych periodykach publikacje swojego autorstwa ${ }^{63}$. Z kolei Centralna Redakcja Zagraniczna w liście do Sekretariatu KC KPZB z 4 VI 1929 r. zwracała uwagę na brak odzewu ze strony członków partii oraz „mas pracujących i włościan” i w związku z tym pytała się o to, czy jest w ogóle prowadzony kolportaż $\mathrm{w}$ terenie czy też cała literatura zalega $\mathrm{w}$ składach ${ }^{64}$. Jako jedną z głównych przyczyn braku popularności komunistycznej literatury wśród zamieszkującej obszar działania KPZB ludności należy uznać fakt, że wśród członków lokalnych struktur KPZB często znajdowali się współpracownicy polskiej policji, którzy wskazywali jej personalia osób otrzymujących komunistyczną literaturę, a niekiedy wręcz podrzucali ją osobom podejrzanym jako dowód w postępowaniu przeciwko nim. W rezultacie z czasem większość białoruskich chłopów po otrzymaniu komunistycznych materiałów niszczyło je bądź oddawało w ręce policji ${ }^{65}$. Wszystkie wspomniane czynniki miały niewątpliwie spory wpływ na późniejsze zmiany w kształcie „Балшавика”. Od numeru 41 (wydanego w grudniu 1930 r.) został on bowiem przekształcony w magazyn liczący ok. 50 stron objętości $\mathrm{w}$ numerze. Zamieszczano w nim głównie artykuły teoretyczne w języku białoruskim. Jedynie od czasu do czasu publikowano oficjalne odezwy partyjne w języku rosyjskim. Znacznie obniżono również nakład pisma, który od roku 1931 mieścił się w granicach 3-5 tysięcy egzemplarzy. Łącznie ukazało się ok. 50 numerów pisma, które zakończyło swój żywot w 1936 roku $^{66}$.

Na początku 1927 r. Komitet Centralny KPZB przystąpił do wydawania w Wilnie kolejnego swojego periodyku pod tytułem „Бюллетень ЦК КПЗБ” („Biuletyn КС KPZB”). W pierwszym numerze pisma, datowanym na 20 I 1927 r. redakcja wyjaśniała cele nowego pisma „[...] КC przystąpiło do wydawania «Бюллетень ЦК» przeznaczonego dla partyjnego aktywu, jak i dla wszystkich partyjnych mas, mając za cel usprawnić pisemne kierownictwo oraz instruktaż partyjnych organizacji w kwestiach agitacji, propagandy [...]”. Redakcja zapowiadała również publikację oficjal-

62 W. Śleszyński, Bezpieczeństwo wewnętrzne w polityce państwa polskiego na ziemiach północno-wschodnich II Rzeczypospolitej, Warszawa 2007, s. 263.

63 Об участии в партыйной печати товарищей с мест, „Бюллетень ЦК КПЗБ”, nr 1(10), 25 III 1928, s. 9.

64 AAN, KPZB sygn. 163/V-88, Korespondencja Centralnej Redakcji Zagranicznej...; Pismo do Sekretariatu CK KPZB..., k. 5.

65 Zob. E. Mironowicz, Białorusini i Ukraińcy w polityce obozu piłsudczykowskiego, Białystok 2007, s. 74, 77.

66 Г. Б. Воткович, op. cit., s. 27; П. И. Зелинский, Н. А. Ракевич, op. cit., s. 8. 
nych oświadczeń KPZB, jak również apelowała do członków partii o przysyłanie do redakcji sprawozdań z własnej działalności agitacyjnej ${ }^{67}$. Do składu redakcji pisma przez plenum KC KPZB zostali wyznaczeni M. A. Blinczykow, S. Budzyński, A. A. Olszewski, L. Rodziewicz, A. Rozenszein, A. Cukierman ${ }^{68}$. Łamy pisma zapełniały najczęściej oficjalne uchwały KC KZPB dotyczące bieżącej działalności partyjnej dla poszczególnych komórek partyjnych. Publikowano w nim również materiały propagandowe dotyczące ZSRR. W pierwszych numerach pisma na ostatniej stronie pojawiała się rubryka informująca o nowościach wydawniczych KPZB oraz KZMZB. Periodyk miał kształt biuletynu, był drukowany typograficznie. Objętość poszczególnych numerów wahała się w granicach 4-16 stron. „Бюллетень” ukazywał się nieregularnie, zdarzały się długie przerwy w wydawaniu. Na przykład pomiędzy ukazaniem się numeru 10 (z 25 III 1928 r.) a 11 (czerwiec 1929 r.) upłynęło ponad 15 miesięcy. Niektóre numery (jak na przykład 8 i 9 z 1927 r.) były wydawane równolegle w języku polskim, białoruskim i jidysz. Pod koniec 1929 r. pismo uległo językowej białorutenizacji i było wydawane pod tytułem „Бюляцень ЦК КПЗБ” (taki tytuł nosi ostatni zachowany numer, datowany na grudzień 1929 r.). Najprawdopodobniej w takiej formie pismo przetrwało do $1936 \mathrm{roku}^{69}$. Tym samym był to jeden z najdłużej ukazujących się organów prasowych KC KPZB.

Pod koniec 1927 r. w Wilnie KC KPZB rozpoczęła wydawanie kolejnego swojego organu prasowego, który tym razem miał koncentrować się wokół zagadnień teoretycznych związanych z ideologią marksizmu oraz propagowaniu rewolucji komunistycznej. Pismo to nosiło tytuł „Пад сцягам камунизму” („Pod sztandarem komunizmu"). Zachował się tylko pierwszy, podwójny numer datowany na listopad-grudzień 1927 roku. W napisanym w języku białoruskim wstępniaku redakcja pisma przedstawiała zadania nowego periodyku: „Za główne zadania czasopisma «Пад сцягам камунизму» uznajemy uzbrojenie partyjnych mas w ostrzejszy oręż leninizmu, jaki jest wykuwany w lepszej leninowskiej kuźni - w WKP(b) pod kierownictwem CK WKP(b) [...]. «Пад сцягам камунизму» poświęci wiele miejsca na swych stronach opracowaniu z punktu widzenia leninizmu tych zagadnień, jakie mają duże znaczenie dla rewolucji proletariackiej na terenie Polski i Z[zachodniej] B [iałorusi] [...]. Nowy organ partii powinien skupić wokół siebie cały aktyw partii i organizować jego teoretyczną pracę" ${ }^{\prime \prime}$. Magazyn ten liczył ponad 150 stron objętości. Choć jego tytuł i nota redakcyjna została napisana w języku białoruskim, to jednak zdecydowana większość zamieszczonych w nim materiałów została opublikowana w języku rosyjskim. Wyjątkiem był m.in. artykuł Józefa Łohinowicza opublikowany pod pseudonimem Paweł Korczyk pod tytułem „Нашы задачы”. Publikowano w nim również polemikę między Georgijem Dymitrowem a Józefem Stalinem. Pismo posiadało stałe działy - „Наша трыбуна”, w którym planowano

67 От редакции, „Бюллетень ЦК КПЗБ”, nr 1, 20 I 1927, s. 1.

68 Революиионный путь Компартии..., s. 187.

69 Taką datę końcową pisma podaje Jerzy Traczuk. Zob. idem, op. cit., s. 326.

70 Ад редакцыи, „Пад сцягам камунизму” nr 1-2, listopad-grudzień 1927, s. 3-4. 
zamieszczać wypowiedzi członków partii dotyczące ich działalności agitatorskiej oraz związanych z tym problemów, a także „Матарьялы и дакуманты”, w których publikowano oficjalne uchwały Międzynarodówki Komunistycznej oraz WKP(b) (mimo białoruskojęzycznych tytułów rubryk, zamieszczano w nich materiały pisane w języku rosyjskim). Nie jest znany czas ukazywania się czasopisma i liczba wydanych numerów, ale z pisma Centralnej Redakcji Zagranicznej do Sekretariatu KPZB wynika, że było ono redagowane jeszcze w połowie $1929 \mathrm{roku}^{71}$.

Pod koniec lat 20. KC KPZB wydawała kolejne dwa czasopisma w języku rosyjskim. Pierwszym z nich był pisany na maszynie oraz odbijany na hektografie „Бюллетень Информационный” („Informacyjny Biuletyn”). Czasopismo to miało charakter informacyjny i było przeznaczone dla członków partii. Nieznane jest jego miejsce wydawania, zachował się tylko 1 numer datowany na lipiec 1929 r., liczący 8 stron objętości. Pismo to informowało o wytycznych organizacyjnych zarówno dla KPZB, jak i powiązanego z nią Komunistycznego Związku Młodzieży Zachodniej Białorusi (KZMZB), a także przedstawiało w propagandowy sposób bieżące „sukcesy” ZSRR. Według P. Zielinskija i M. Rakiewicza, pismo ukazywało się do roku 1930 i wyszły łącznie trzy jego numery ${ }^{72}$. W latach $1929-1930^{73}$ KPZB wydawała nieregularnie również pismo pod tytułem „Бюллетень (выписки из пресси)” („Biuletyn (wypiski z prasy)"), pełniący funkcję partyjnego przeglądu prasowego. Miejsce wydawania „Бюллетеньу" jest nieznane, pismo to również było przygotowywane na maszynie i odbijane na hektografie. Poszczególne numery liczyły od 8 do 20 stron objętości. $\mathrm{Na}$ łamach pisma zamieszczano głównie teksty z prasy sowieckiej (niekiedy także z prasy komunistycznej z Zachodu) dotyczące sytuacji w ZSRR oraz komunistycznych zamieszek w Polsce i innych krajach zachodnich. Najczęściej cytowanymi na łamach „Бюллетеньу” gazetami były sowiecka „Правда” oraz „Известия”, w nieco mniejszym stopniu także niemiecki „Die Rote Fahne”. Według P. Zielinskija i M. Rakiewicza ukazało się łącznie 7 numerów pisma ${ }^{74}$.

Mimo faktycznych niepowodzeń kolejnych inicjatyw wydawniczych kierownictwo partii nie miało najmniejszych zamiarów zaprzestać działalności prasowej. W roku 1930 Komitet Centralny partii apelował do komitetów okręgowych w terenie o zakładanie na swoim obszarze działań własnych podziemnych typografii i hektografów, a także podziemnych gazet na terenie fabryk oraz tartaków, dystrybuowanie ich wśród miejscowej ludności oraz pozyskiwanie korespondentów wśród miejscowych robotników i chłopów ${ }^{75}$. Ponadto w celu poprawy dystrybucji prasy i literatury komunistycznej w terenie KC KPZB w marcu $1931 \mathrm{r}$. apelowała do poszczególnych Okręgowych Komitetów o przysyłanie sprawozdań dotyczących możliwości oraz przebiegu dystrybuowania w terenie materiałów propagandowych,

71 AAN, KPZB sygn. 163/V-88, Korespondencja Centralnej Redakcji Zagranicznej z Centralną Redakcją Krajową KPZB; Pismo do Sekretariatu CK KPZB z 4 VI 1929, k. 6.

72 П. И. Зелинский, Н. А. Ракевич; ор. cit., s. 8.

73 Ibidem.

74 Ibidem.

75 AAN, KPZB sygn. 163/V-56, Sprawozdanie...; Некоторые уроки..., k. 64. 
a także informowanie o tym, na jakie konkretnie materiały jest zapotrzebowanie na obszarze działania członków partii ${ }^{76}$. Tymczasem Komitet Centralny rozpoczął wydawanie kolejnego pisma $\mathrm{w}$ języku rosyjskim, które tym razem miało odegrać znacznie poważniejszą rolę $\mathrm{w}$ działalności propagandowej partii.

Od roku 1929 aż do roku 1937 zaczęło się ukazywać w Wilnie ${ }^{77}$ kolejne wydawane przez KC KPZB czasopismo noszące tytuł „Партработник”. Tytuł ten był skrótem od „партийны работник”78, со można przetłumaczyć po polsku „działacz partyjny". Pismo w założeniach miało być miesięcznikiem, często jednak ukazywało się nieregularnie. „Партработник” jako jeden z nielicznych organów prasowych KC KPZB był drukowany drukiem typograficznym. Jego cena wynosiła 20 groszy. $\mathrm{Na}$ ostatniej stronie 4 numeru pisma z grudnia 1930 r. redakcja deklarowała, że jej celem będzie publikowanie sprawozdań z działalności lokalnych jaczejek, poruszanie kwestii związanych z działalnością partii, zamieszczanie oficjalnych instrukcji partyjnych oraz materiałów z ZSRR. Zwracano również uwagę członkom partii, że pismo spełni swoje zadanie, tylko jeżeli członkowie KPZB „wezmą w nim aktywny udział". W związku z tym apelowano do nich o przysyłanie do redakcji pisma sprawozdań ze swojej partyjnej działalności ${ }^{79}$.

Również Komitet Centralny KPZB w instrukcjach do jaczejek apelował o wykorzystywanie łamów „Партработника” w przesyłaniu sprawozdań z bieżącej działalności w terenie ${ }^{80}$. W różnych okresach zmieniał się format pisma i jego objętość, która najczęściej wynosiła 16 stron, bywały jednak okresy, kiedy wahała w granicach 6-12 stron. Na łamach „Партработника” publikowano oficjalnie odezwy KPP i KPZB, sprawozdania $\mathrm{z}$ działań $\mathrm{w}$ terenie lokalnych jaczejek (szczególnie często z obszaru województwa białostockiego), a także instrukcje skierowane do członków partii w sprawie działalności propagandowej, na przykład działalności antywojennej „w obronie ZSRR”. „Партработник” posiadał stały dział „Комсомолец”, później przemianowany na „Страница комсомольца”, w którym zamieszczano sprawozdania z działalności KZMZB. Na łamach pisma informowano również o przypadkach wyrzucenia $\mathrm{z}$ partii oraz publikowano nazwiska zdemaskowanych prowokatorów policyjnych. Pismo od początku napotykało różne problemy. Pierwszy numer (który nie zachował się w zbiorach archiwalnych i bibliotecznych) był pełen licznych literówek, które autorzy mieli popełnić „,z przyczyn technicznych”. Redakcja opublikowała stosowne sprostowanie dopiero w numerze $5 \mathrm{z}$ grudnia $1930 \mathrm{roku}^{81}$.

Członkowie partii najwyraźniej nie płacili również zbyt często składek przeznaczonych na wydawanie pisma, gdyż redakcja była zmuszona publikować ogłoszenia

76 AAN, KPZB sygn. 163/V-57, Sekretariat KC. Sprawozdania z działalności; Поправка к первомайскому цыркуляру, k. 1-3.

77 J. Traczuk, op. cit., s. 328. P. I. Zielinskij i N. A. Rakiewicz podają błędnie lata 1930-1932 jako czas wydawania pisma. Zob. idem, op. cit., s. 8.

78 A. Bergman, Sprawy białoruskie..., s. 28.

79 От редакции „Партработника”, „Партработник”, nr 1(4), listopad 1930, s. 16.

80 AAN, KPZB sygn. 163/V-56, Sprawozdanie z działalności; Некоторые уроки 25 февраля, k. 65.

81 Исправления, „Партработник”, nr 2(5), grudzień 1930, s. 16. 
przypominające im o konieczności spełnienia tego obowiązku ${ }^{82}$. Nie było również w szeregach członków partii zbyt wielu chętnych do czytania oraz kolportowania tegoż pisma, gdyż redakcja informowała dla przykładu o tym, że w czasie jednej z kontroli składu lokalnej komórki partyjnej znaleziono 50 nierozprowadzonych egzemplarzy „Партработника”; z kolei w Wilnie w tym czasie w ogóle literatura partyjna nie była dostępna. W związku z tym redakcja przypominała, że powinnością członków partii jest nie tylko czytanie „Партработника”, „Балшавика” i innych czasopism partyjnych, lecz także ich regularne rozpowszechnianie ${ }^{83}$. Od roku 1931 periodyk ten ukazywał się już niemal wyłącznie w języku białoruskim (w niektórych numerach część materiałów publikowano nawet $\mathrm{w}$ języku polskim) ${ }^{84}$. W związku z tym nieprawdziwa jest informacja podana przez Aleksandrę Bergman, jakoby pismo „ukazywało się zawsze w języku rosyjskim" ${ }^{25}$. Wyjątkiem były numery z marca oraz kwietnia 1932 r., które wydano w języku rosyjskim, jednak, jak tłumaczyła redakcja, rozwiązanie to zastosowano „z przyczyn technicznych”86. „Партработник” przez pewien czas posiadał również dodatek, jakim był „Прессовий Бюллетень” („Biuletyn prasowy”), wydawany w Wilnie najprawdopodobniej od $1930 \mathrm{r}^{87}$ (będący prawdopodobnie kontynuacją wspomnianego w poprzednim akapicie czasopisma „Бюллетень”). Jako samodzielne pismo kosztował on 8 groszy. Zachował się jednak tylko jeden jego numer, datowany na marzec 1931 roku. Jeżeli chodzi o samego „Партработника”, to wiadomo, że ukazywał się on jeszcze wiosną 1937 r., gdyż, jak wspomina Mikołaj Orechwo, właśnie wtedy przedrukowano w nim artykuł z organu KPP „Nowy Przegląd” pod tytułem „Dywersja piłsudczyzny w radach KPZB” będący zapowiedzią likwidacji tej partii ${ }^{88}$.

Choć około roku 1932 czołowe organy prasowe KC KPZB były już zbiałorutenizowane, to $\mathrm{w}$ tym czasie partia ta wydawała jeszcze kilka efemerycznych periodyków w języku rosyjskim. Pierwszym z nich był wydawany w roku 1932 w Wilnie „Политинформатор” (skrót od „Политический Информатор” - „Informator polityczny"), który był przeznaczony dla członków KPZB. Zachowały się dwa numery tego pisma - nr 3 (datowany na koniec maja 1932 r.) oraz nr 5 (datowany na sierpień tego roku), liczące odpowiednio 7 i 6 stron objętości. Pismo to, podobnie jak większość opisywanych w tym artykule, również było przygotowywane na maszynie do pisania, a następnie powielane na hektografie. Ukazywało się nieregularnie. „Политинформатор” wydawany był przez Centralny Komitet KPZB. Na pierwszej stronie pisma apelowano do "partyjnego aktywu” nie tylko o czytanie pisma, ale także o wykorzystywanie zamieszczonych w nim materiałów do pracy agitacyjnej.

82 Tego typu ogłoszenie ukazało się na przykład w numerze 5(17) z maja $1932 \mathrm{r}$.

83 Внимание вопросам колпортажа партыйной литературы, „Партработник”, nr 3, marzec 1932, s. 9-10.

84 Zob. także J. Traczuk, op. cit., s. 299.

85 A. Bergman, Sprawy białoruskie..., s. 28.

86 „Партработник”, nr 3, marzec 1932, s. 12.

87 J. Traczuk jako datę wydawania pisma podaje 1931 rok. Zob. idem, op. cit., s. 329.

88 H. C. Орехво, op. cit., s. 228-229. 
Poszczególne numery pisma koncentrowały się na jednej wybranej tematyce. Numery 1 i 2 zostały poświęcone kwestii zagrożenia wojennego ${ }^{89}$. Z kolei treść numeru 3 koncentrowała się głównie na informowaniu o strajkach robotniczych na terenie północno-wschodnich województw II Rzeczypospolitej oraz prowadzonym przez „faszystowskie władze” polskie „krwawym terrorze” w reakcji na nie. W numerze 5 sporo miejsca poświęcono „walce klasowej” w Niemczech. Wśród wydawanych w tym czasie rosyjskojęzycznych periodyków KPZB znajdowały się również te poświęcone obronie ZSRR przed „oszczerstwami” ze strony „imperialistów”. Zaliczyć do nich można wydawane w pierwszej połowie lat 30. w Wilnie „Антивоенный Бюллетень” („Biuletyn Antywojenny”) oraz „Из соцялистическаго отечества” („Z socjalistycznej ojczyzny"). O tym pierwszym piśmie, według Jerzego Traczuka wydawanego w latach 1932-1933 ${ }^{90}$, nie da się zbyt wiele powiedzieć ze względu na fakt, iż zachował się tylko jeden jego numer datowany na wrzesień 1932 roku. Jego objętość wynosiła 14 stron, kolejne numery przygotowywano na maszynie do pisania oraz odbijano na hektografie. Tak jak wskazywała jego nazwa zajmowało się ono propagowaniem działań mających zapobiec wojnie (oczywiście tej wymierzonej w ZSRR). Oprócz informowania o wszelkich przejawach działań państw zachodnich (w tym Polski) mających zdaniem redakcji świadczyć o próbach rozpętania wojny przeciwko ZSRR pismo informowało o wszelkiego rodzaju „pokojowych kongresach”, organizowanych przez środowiska powiązane z Międzynarodówką Komunistyczną w różnych krajach zachodnich. Część artykułów „Бюллетеньу” była redagowana w języku białoruskim ${ }^{91}$.

Na hektografie było powielane również „Из соцялистическаго отечества”. Zachowały się dwa numery tego pisma, datowane na styczeń oraz sierpień 1933, które liczyły odpowiednio 6 i 8 stron objętości. Stawiało sobie ono za cel „dać każdemu członkowi partii i komsomołu a także bezrobotnemu rewolucyjnemu aktywowi materiał dla informowania szerokich robotniczych i włościańskich mas o sukcesach i trudnościach socjalistycznej ojczyzny, o sprawach związanych z wewnętrznym i zewnętrznym położeniem ZSRR"92. Pismo zawierało propagandowe materiały opiewające rzekome sukcesy ZSRR w realizowaniu „drugiej pięciolatki”, postępy socjalizmu w Białoruskiej SRR, a także informowało o rzekomych aktach sabotażu w czasie trwającej wówczas kolektywizacji rolnictwa (nie wspominając nic oczywiście o osiągającej wówczas apogeum klęsce Wielkiego Głodu). Co ciekawe, autor jednego z okólników wydawniczych krytycznie ocenił działalność propagandową redaktorów, pisząc: „Biuletyn «Из соцялистическаго отечества» daje gołe, suche cyfry, które nikogo nie przekonują, a w artykułach i odezwach wy ograniczacie się staremi ogólnikowemi frazesami, bardzo słabo reagujecie na szaloną i oszczerczą kampanię o głodzie w ZSRR, którą rozwinęła cała burżuazja" ${ }^{33}$. Warto zwrócić uwagę, że te broniące dobrego imienia

89 „Политинформатор”, nr 3, koniec maja 1932, s. 1.

90 J. Traczuk, op. cit., s. 326.

91 Ibidem.

92 „Из соцялистическаго отечества”, nr 4, sierpień 1933, s. 1.

93 Archiwum Państwowe w Białymstoku (APB), KW PZPR sygn. 3098, Okólniki i pisma ogólne CK KZMBZ i ocena wydawnicza, k. 84-85. 
„ojczyzny światowego proletariatu” periodyki były wydawane w czasie, gdy ta rozpoczynała prześladowania przebywających na jej terenie czołowych działaczy KPZB.

W tym okresie bowiem na terenie ZSRR rozpoczęły się pierwsze represje wymierzone w tych białoruskich komunistów, którzy początkowo byli działaczami białoruskiego ruchu narodowego. Właśnie w roku 1933 uwięziono kilkunastu działaczy KPZB, w tym redaktora „Балшавика” Leopolda Rodziewicza, któremu przypomniano działalność w BOR oraz „Secesji”. Wkrótce co prawda odzyskał on wolność, ale został zmuszony do przeniesienia się w głąb ZSRR oraz rezygnacji z działalności redaktorskiej oraz literackiej ${ }^{94}$. Mimo tego KPZB wciąż funkcjonowała, podobnie jak jej redakcja oraz wydawane przez nią partyjne periodyki. Około roku $1935 \mathrm{w}$ skład centralnej redakcji KPZB wchodzili S. Budzyński, J. Brun, G. Smolar, D. Rozenstein, S. Malko, A. Olkin ${ }^{95}$. Jednakże już wtedy KPZB ze względu na zbyt wielkie ryzyko stopniowo ograniczała tzw. „akcję techniczną” polegającą na kolportażu partyjnych druków ${ }^{96}$, o czym świadczyła również stopniowa likwidacja jej organów partyjnych. W roku 1936 przestał się ukazywać „Бюляцень ЦК КПЗБ” oraz „Балшавик”. Z kolei w listopadzie 1937 r. kierownictwo Międzynarodówki Komunistycznej zabroniło KPZB prowadzenia działalności wydawniczej ${ }^{97}$. Zapewne mniej więcej w tym czasie likwidacji uległ również „Партработник” oraz „Чырвоны Сцяг”. Rozpoczęły się również masowe aresztowania członków KPP, KPZB oraz KPZU na terenie Ukrainy. Dwudziestego ósmego dnia tego miesiąca kierownictwo Międzynarodówki Komunistycznej (MK) podjęło decyzję o rozwiązaniu wymienionych partii, co Stalin zaakceptował cztery dni później. Formalne ogłoszenie tej decyzji miało miejsce w dniu 16 VIII 1938 roku $^{98}$. W tym samym roku wielu aresztowanych członków partii straciło życie, $w$ tym, między innymi były redaktor „Балшавика” Leopold Rodziewicz ${ }^{99}$. Wielu czołowych białoruskich komunistów tym samym zostało zabitych z woli władz państwa, któremu oddanie służyli przez wcześniejsze kilkanaście lat...

$\mathrm{W}$ ostatecznym rozrachunku trudno o pozytywną ocenę rosyjskojęzycznej prasy KC KPZB wydawanej w czasie istnienia tej partii. Spośród opisanych w niniejszej pracy 10 czasopism wydawanych częściowo bądź całkowicie w tym języku, jedynie trzy („Болшевик”, „Партработник” oraz „Бюллетень ЦК КПЗБ”) ukazywały się dłużej niż dwa lata, przy czym przez zdecydowaną większość swojego istnienia były one wydawane w języku białoruskim. $Z$ powodu konspiracyjnych warunków wydawania prasy partyjnej KPZB jej jakość nie stała na wysokim poziomie (poza wspomnianymi wcześniej czołowymi tytułami była ona odbijana na hektografie), a fakt, że w znacznym stopniu była ona również przygotowywana poza granicami Polski (w Mińsku, gdzie mieściła się siedziba Zagranicznej Redakcji KPZB) również utrudniał przygotowanie kolejnych numerów, pozyskiwanie materiałów do nich oraz ich dystrybuowanie.

94 A. Bergman, Sprawy białoruskie..., s. 217-218.

95 Р. В. Булацки, И. И. Сачанка, С. В. Говин; ор. cit., s. 263.

96 Zob. P. Cichoracki, op. cit., s. 192.

97 H. Cimek, Komuniści-Polska-Stalin..., s. 124.

98 Ibidem, s. 122-124, 127; idem, Białorusini w ruchu rewolucyjnym..., s. 26.

99 A. Bergman, Sprawy białoruskie..., s. 218. 
Kolejnymi czynnikami utrudniającymi bądź wręcz uniemożliwiającymi sukces wydawniczy była działalność polskiej policji w wielu wypadkach skutecznie uniemożliwiającej kolportaż wspomnianej prasy, a także niepłacenie przez członków partii składek członkowskich. Fakt nieczytania przez znaczną część członków partii wspomnianych gazet również wpływał negatywnie na ich kształt, gdyż z powodu niewielkiej ilości korespondencji oraz sprawozdań z terenu redakcje pism miały problem z wydaniem kolejnych numerów. Wreszcie kolejną przyczyną niepowodzeń wspomnianych czasopism był fakt wydawania ich w języku rosyjskim, który był językiem ojczystym jedynie dla niewielkiej liczby mieszkańców tzw. Zachodniej Białorusi (wśród których było niewielu członków i zwolenników tej partii). Choć starsze pokolenie mieszkańców terenów, na których działało KPZB znało dobrze ów język jeszcze z czasów przynależności tych ziem do Rosji, to młodsze wychowane już w II Rzeczypospolitej wolało posługiwać się swoimi językami ojczystymi, jak również w nich czytać prasę, $\mathrm{w}$ dodatku legalną. Tymczasem tego drugiego warunku organy prasowe KC KPZB nie spełniały, choć były one w stanie „przekierować się” na język białoruski. Mimo że propagowane przez wspomnianą prasę „zjednoczenie” ziem „Zachodniej Białorusi” z ZSRR ostatecznie miało się spełnić w roku 1939, to zarówno wspomniane periodyki, jak i większość redagujących je członków partii, jak i wreszcie sama partia nie doczekali tego wydarzenia, padając ofiarą Wielkiego Terroru rozpętanego przez tak przez nich wielbionego Józefa Stalina w latach 1937-1938.

\section{The Russian-language press of the Central Committee of the Communist Party of Western Belarus (CC CPWB)}

Among the many press titles published illegally by the Central Committee of the Communist Party of Western Belarus (CC CPWB) during the Second Polish Republic, about a dozen were published partly or entirely in Russian. All of these periodicals were published in Vilnius (where were located underground printing offices adapted for this purpose) and in Minsk (where the so-called Foreign Editorial Office of the CPWB was located). Save for a few leading titles that were printed typographically (and were probably created mainly in the USSR), these periodicals were written on a typewriter and then duplicated on a hectograph. According to party leaders, these press titles were supposed to inform regular CPWB members about the activities and objectives of the party and play a subsidiary role in party propaganda. However, most of them did not last long or enjoy wider popularity among party members who, according to internal party documents and articles or communiqués published in said periodicals, did not read these newspapers, nor did they send any correspondence or reports, or even pay contributions. In order to increase the popularity of these press titles, their language was usually switched gradually to Belarusian; however, this solution eventually failed to produce any important results, inter alia due to operations by the Polish police, which effectively undermined the activities of the party, including that in distributing illegal press and literature. The Stalinist repression of 1932-1933 directed against party members with a nationalist past was a prelude to the dissolution of CPWB in 1938 (it is worth noting that all press organs of the party, including those described in this article, had been closed even earlier, in the years 1936-1937). 


\section{Русскоязычная пресса Центрального комитета Коммунистической партии Западной Белоруссии (ЦК КПЗБ)}

Среди многочисленной нелегальной прессы, издаваемой Центральным комитетом Коммунистической партии Западной Белоруссии (КПЗБ) на территории II Речи Посполитой было также более десяти изданий, частично или полностью, русскоязычных. Все они печатались в Вильне (где размещались, приспособленные для этого, подпольные печатни), а также на территории СССР, в Минске (где находилась штаб-квартира т. н. Зарубежной редакции КПЗБ). Кроме нескольких главных изданий, которые тиражировались типографическим методом (и, вероятнее всего, главным образом на территории СССР), остальные печатались на пишущих машинках или отпечатывались на гектографе. По идее руководства партии эта пресса должна была информировать рядовых членов КПЗБ о деятельности и целях партии, а также играть вспомогательную роль в пропагандистской и партийной деятельности. На практике, однако, большинство журналов не функционировало слишком долго и не пользовалось излишней популярностью среди членов партии, которые, как следует из партийных документов, а также статей и партийных коммюнике, напечатанных на страницах этих изданий, не читали их, не присылали корреспондентских статей и отчетов, а также не оплачивали взносы. Для увеличения популярности этих изданий, обычно, спустя некоторое время, их языковый профиль постепенно менялся на белорусский, на практике, однако, это не приносило больших результатов, что было вызвано м. пр. деятельностью польских полицейских служб, которые эффективно торпедировали деятельность партии, включая ту, проявляющуюся в распространении нелегальной прессы и литературы. Сталинские репрессии в 1932-1933гг., направленные на членов КПЗБ с националистским прошлым, стали прелюдией к роспуску партии в 1938г. (стоит отметит, что все печатные органы КПЗБ, включая описанные в данной статье, были закрыты еще раньше в 1936-1937гг.).

Перевод Агнешка Поспишьль

\section{Bibliografia:}

Bergman A., Sprawy białoruskie w II Rzeczypospolitej, Państwowe Wydawnictwa Naukowe, Warszawa 1984.

Cimek H., Białorusini w ruchu rewolucyjnym w II Rzeczypospolitej, [w:] Kwestia narodowościowa $w$ Polsce i we Włoszech w XX wieku. Wybrane problemy, red. idem, Wydawnictwo Uniwersytetu Rzeszowskiego Rzeszów 2011, s. 11-34.

Cimek H., Komuniści-Polska-Stalin, Krajowa Agencja Wydawnicza, Białystok 1990.

Cimek H., Mniejszości narodowe w ruchu rewolucyjnym w II Rzeczypospolitej, Wydawnictwo Uniwersytetu Rzeszowskiego, Rzeszów 2011.

Cimek H., Sojusz robotniczo-chłopski w Polsce 1918-1939, Książka i Wiedza, Warszawa 1989.

Gomółka K., Białorusini w II Rzeczypospolitej, [w:] „Zeszyty Naukowe Politechniki Gdańskiej” 495, Ekonomia XXXI, Wydawnictwo Politechniki Gdańskiej, Gdańsk 1992.

Januszewska-Jurkiewicz J., Stosunki narodowościowe na Wileńszczyźnie w latach 1920-1939, Wydawnictwo UŚ, Katowice 2010.

Łukasiewicz S., Zdrada stanu. Działalność Komunistycznej Partii Zachodniej Białorusi w Wilnie w latach 1930-1935, „Ogrody nauk i sztuk”, nr 2, 2012, s. 75-86.

Mironowicz E., Białorusini i Ukraincy w polityce obozu piłsudczykowskiego, Wydawnictwo Uniwersyteckie Trans Humana, Białystok 2007. 
Mironowicz E., Prasa białoruska pod okiem rosyjskiej i polskiej cenzury, „Białoruskie Zeszyty Historyczne", nr 1(5), 1996.

Pacuk J., Ksztattowanie się stosunku KPP i KPZB do powstania zbrojnego (1924-1925), [w:] „Zeszyty Naukowe Instytutu Nauk Politycznych", t. II, 1975, s. 161-179.

Rudnicki Sz., Nieznany dokument w sprawie Sylwestra Wojewódzkiego, „Przegląd Historyczny”, t. 47,1976 , z. 1, s. 71-84.

Słownik biograficzny działaczy polskiego ruchu robotniczego, red. Tych F., t. 2, wyd. Książka i Wiedza, Warszawa 1987.

Suławka A. R., Prasa rosyjskojęzyczna Niezależnej Partii Chłopskiej (NPCh) w latach 1924-1927, „Białoruskie Zeszyty Historyczne”, nr 41, 2014, s. 107-125.

Śleszyński W., Bezpieczeństwo wewnętrzne w polityce państwa polskiego na ziemiach pótnocno-wschodnich II Rzeczypospolitej, wyd. Rytm, Białystok 2007.

Śleszyński W., Walka instytucji państwowych z białoruską działalnościa dywersyjna na ziemiach pótnocno-wschodnich II Rzeczypospolitej, [w:] W. Śleszyński, Walka instytucji państwowych $z$ białoruska działalnościq dywersyjna 1920-1925, Wydawnictwo Prymat, Białystok 2005.

Tomaszewski J., Ojczyzna nie tylko Polaków. Mniejszości narodowe w Polsce w latach 1918-1939, Młodzieżowa Agencja Wydawnicza, Warszawa 1985.

Traczuk J., Prasa białoruska w II Rzeczypospolitej (1918-1939), [w:] „Studia polono-slavica orientalia. Acta litteraria", t. XIII, 1992, s. 185-342.

Zachariasz S., Józef Łohinowicz (Paweł Korczyk), „Z Pola Walki”, nr 3(15), 1961, s. 212-237.

Zielińska N., Zieliński K., Prasowe inicjatywy wydawnicze Towarzystwa Straży Kresowej w latach 1918-1922, [w:] „Studia Bibliologiczne Akademii Świętokrzyskiej”, t. VII, 2003, s. 63-79.

Булацки Р. В., Сачанка И. И., Говин С. В.; Гисторыя беларускай журналистыки, Выдавецтва БДУ имя У. И. Леніна, Mińsk 1979.

Воткович Г. Б., КПЗБ в борьбе за интернационалное единство трудящихся (1929-1933 г2.), Выдавецтва БДУ имя У. И. Леніна, Mińsk 1975.

Глинская Т., КПЗБ - руководитель освободительной борьбы трудящихся Западной Белоруссии 1924-1928 г2., Издательство Беларусь, Mińsk 1965.

Зелинский П. И., Ракевич Н. А., Печать КПЗБ в борьбе за свободу, Выдавецтва БДУ имя У. И. Леніна, Mińsk 1977.

Ладысев В. Ф., КПЗБ - арганизатар барацьбы працоўных за демакратычныя правы и свабоды (1934-1938 г2.), Выдавецтва БДУ имя У. И. Леніна, Mińsk 1976.

Ладысев В. Ф., В борьбе за демократические права и свободы, Издательство Беларусь, Mińsk 1988.

Лугачиова Т. А., Международная Организащия Помощи Революиионерам (МОПР) в Западной Белоруссии (1923-1939 г.), ГрГУ, Grodno 2001.

Лугачиова Т. А., Печать МОПРа Западной Белоруссии как источник изучения деятельности организации в 20-30-є г2. ХХ в., [w:] Актуалныя праблемы крынииазнауствва айчыннай гисторыи, red. Дулаў А. М., wуd. ВДУ імя П.М. Машэрава Witebsk 2011.

Революционньй путь Компартии Западной Белоруссии, red. Мацко А., Самутин В., Государственное Издательство БССР, Mińsk 1966.

Полуян В. А., Революиионно-демократическое движение в Западной Белоруссии, Наука и техника, Mińsk 1978.

mgr Adam Radosław Suławka - doktorant w Instytucie Historycznym Uniwersytetu Warszawskiego. Zainteresowania badawcze dotyczą historii społecznej i politycznej Europy Środkowo-Wschodniej w XIX i XX wieku. (valdas1989@o2.pl) 